\title{
Liberal Arts, generic skills and the aims of education
}

\author{
JĀNIS (JoHN) TĀLIVALDIS OzOLIŅŠ
}

Australian Catholic University

\section{Introduction}

There is no doubt that the more education that a person has, the better his or her life chances. Clearly, such individuals are more employable as they have more skills, are more adaptable and are more productive. Nonetheless, education seen from an economic perspective provides a highly reduced conception of education, limiting its ends to instrumental ones. Seen only in terms of what is necessary to meet the needs of employers and employees, it has only a utilitarian purpose in which goods and services are exchanged in essentially an economic transaction. In the neo-liberal, economic rationalist conception of education, although the needs and wants of the individual are emphasised and education is seen as being a matter of choice, the conception of the human individual is in terms of his or her function within society. The rhetoric argues for the growth and fulfilment of the individual person, but this is not unbounded and is instead constrained by a conception of education which demands measureable outcomes from a course of study.

What we seek to argue is not that the acquisition of practical skills which enable persons to be employed is a bad thing nor that teachers ought not strive to teach well and to have some means of determining whether their pupils have learnt what was taught. It is rather to argue that there is much more to education and there is much to learn from older conceptions of education which emphasise the liberal arts and which highlight the importance of having a grasp of how disparate skills, facts and theories are connected. In particular, we want to argue that the central and most important aim of education is the quest for wisdom and when we talk about lifelong learning it is this which should properly be meant, since this is an open-ended quest. The importance of wisdom as the central aim of education has a long history and a thorough account of this remains to be written. Our aim here is to briefly survey three thinkers who have taken seriously the idea that the central aim of education is the gaining of wisdom and to provide the contours of their central arguments. The three thinkers on whom we concentrate, Whitehead, Vico and Bonaventure, are separated by a number of centuries, but in different ways, they support the same conception of education as a quest for wisdom. What they each offer is an insight into an educational task which is far harder to achieve than simply training individuals to have a set of skills or instructing them in professional codes of ethics. Genuine wisdom demands an orientation to the good, a burning desire to quest more deeply for the truth and a willingness to search for a profound understanding of the interconnectedness of our knowledge of the world. Wisdom does seem to be elusive, intangible and ineffable, but is, for all that, more real than what is available to the senses, as Bonaventure argues. Essentially, all three thinkers see the quest for wisdom as a search for God, and so education has an irreducibly religious aspect.

\section{Wisdom as an aim of education}

Whitehead acerbically remarks that in the schools of antiquity philosophers aspired to impart wisdom, whereas in modern colleges the aim is much humbler, it is to teach textbook subjects and the consequent drop from the goal of attaining divine wisdom marks an educational failure. Whitehead sees the acquisition of skills and of a package of useful snippets of knowledge as leading to stagnation because it does not lead to a mastery of knowledge. More particularly, he says that though the acquisition of knowledge is crucial, what is more important, though it is vaguer, is wisdom. (Whitehead, 1962: 45-46) In Whitehead's view, wisdom can only be acquired through freedom in the presence of knowledge, but the only way to knowledge is through discipline. (Whitehead, 1962: 47) There is, therefore, a tension between freedom and discipline. Of course, he adds, in an ideal education discipline should be freely chosen and discipline itself should point to the possibility of freedom. (Ibid.) There is a natural rhythm to education which requires alternately freedom and discipline, but over and above these cycles is the importance of capturing the interest of pupils and this 
can be done either by coercion or through exciting in them a joy of learning. This can be brought about by offering a goal which is realisable and hence will motivate the pupils to pursue it. In attaining knowledge, he says, it is vital that the pupils achieve active mastery over it. Knowledge should not be inert, but must transform every aspect of experience, by which Whitehead means that knowledge must bear fruit and not simply be arid knowledge that is confined to the dusty recesses of the mind. It is this active, transformative knowledge which he calls wisdom. (1962: 48-49)

Whitehead notes that the child has an innate curiosity and a craving for wisdom and that good teaching takes advantage of this and that the environment best suited to the development of the child should selected. Education, he says, is not a process of packing articles in a trunk, but is more like the way in which food is assimilated into an organism. (1962: 50-51) This is an apt metaphor, and it is one which encapsulates the idea that knowledge to be meaningful must become part of the fabric of the being of the person, and wisdom can only be gained if the knowledge acquired is actively employed. Whitehead notes that one ought to get one's knowledge quickly and to use it, because in this way, the knowledge gained will be retained. Through the process of actively using knowledge, the learner comes to know the principles on which the knowledge is based and hence, begins to gain wisdom. It is not the mechanical acquisition of vast quantities of facts that leads us to knowledge, but the growing acquisition of the principles which order the knowledge gained and which enable its deployment in determining how to act. The wise individual does not simply acquire more and more individual pieces of knowledge, but an understanding of the fundamental principles which connect different pieces of knowledge and how these principles enable the person to decide upon a course of action. (1962: 57-58) Whitehead does not think that the aimless acquisition of more and more individual items of knowledge is education at all. ${ }^{1}$

Education, he says, is the guidance of the individual towards a comprehension of the art of life, by which he means a fulfilled life of varied activity in which the full potential of the individual is realised. This involves an artistic sense in which the lower possibilities of the individual are subordinated to the higher and science, art, religion and morality are valued because of the contribution they make to the growth of the individual personality. Each individual embodies an adventure of existence and it is the art of life which guides the adventure. Religion and morality, he continues, should not be a matter of enumerating rules, but of acquiring, through an unfolding at the right stage of development, the principles underlying the religious and moral values that are being taught. He remarks that the teacher's role in teaching these principles is to awaken in the pupil the sense of wonder, of importance, of curiosity, of reverence and of the tumultuous desire of merging personality in something beyond itself. (1962: 61-63) As we shall see below, this last remark is of considerable importance, since it brings us to a meeting point between Whitehead's conception of education as the pursuit of wisdom with that of Bonaventure, who draws heavily on both Aristotle and Augustine. The idea of education as the pursuit of wisdom is, of course, also argued by Bonaventure's great contemporary, Thomas Aquinas. It is this notion of merging the personality with what is beyond itself and which is ultimately ineffable that we can see a clear link between Whitehead and Bonaventure. Before we move on to a consideration of Bonaventure's conception of the purpose of education as wisdom, we will briefly turn to Vico's ideas about education.

\section{Vico, wisdom and the common good}

Giambattista Vico stands as a convenient bridge between what we might call the modern world of universal education of which Whitehead saw the beginning and the older medieval conception of education which is represented by Bonaventure, Aquinas and Augustine and in whom the ultimate point of education is union with God who is Wisdom personified. In Vico we see an account of a humanistic education in which this ultimate goal is recognised, but which shifts the focus more firmly onto the individual. God as the ultimate goal of education, however, is more clearly recognised as the Judaeo-Christian God, Who has not as yet become as ineffable as He has in Whitehead. ${ }^{2}$

In his first oration, Vico argues that the greatest incentive for anyone to acquire learning is to know herself or himself. The wisest precept, he says, that anyone has been given is the Delphic admonition, "know 
thyself". He agrees with Cicero who says that it means that you ought to know your own spirit and, moreover, that the force of this is that it is a divine command. (Vico, 1993: 38-39) We have here a very theological view of human fulfilment, where discovering what it is to be a particular person - to be an individual - is not simply something which we might consider doing or not, but is ordained by divine command. The wise person learns firstly about herself or himself, her or his strengths, talents and weaknesses. This view is also found in Plato, Alcibiades I.124a: "O my friend, be persuaded by me, and hear the Delphic inscription, "Know thyself". ${ }^{3}$ Vico's appeal is to the development here of the spirit and to the desirability of growth in wisdom, since without it, a human being can hardly understand that of which he or she is capable. Moreover, Vico freely acknowledges that such development has a cost: it takes great effort to keep one's own mind free from its accustomed ways and to be in control of the senses. Of significance too is Vico's recognition that in the attempt to know oneself, the person also perceives in herself the divinity of her spirit and that she is made in the image of God. (Vico, 1993: 40) Of course, we need not appeal to God to recognise the mysteriousness of the human soul which expresses the uniqueness of each human being and the creative capacities that each person has. These creative capacities are expressed in different ways through all of the activities of human beings, through the sciences, the arts and the humanities. We do not seek to know what it is to be human through looking at our DNA, but through the activities of human beings, that is, through what they do and we come to know who we are through the same means.

In New Science, Vico says that it is the social nature of human beings that is humanity's most characteristic property. (Vico, 1999: 2) Later, Vico says that he bases his analysis of the origins of human institutions on three principles (1) divine providence, (2) solemn matrimony and (3) universal belief in the immortality of the soul. This analysis bases the origins of human institutions firmly in an observation of human activity in the natural world, reflection on this activity as well as what it is to be human, and a theorising that, in order to lead to human fulfilment, it must follow natural laws which are ordained by God. (Vico, 1999: 8-9) ${ }^{4}$

Vico's claim contrasts very significantly with modern and postmodern views and indeed, these three principles constitute what Lyotard has called 'grand narratives'. It is quite obvious that the postmodern contemporary world does not take seriously any of these three principles nor the view that there are a natural laws which guide human fulfilment. There are a number of reaons which we might adduce why this is so, but amongst them are the following two general reasons. Firstly, the description of the primitive societies recounted by Vico and which formed the basis for abstracting the three principles does not describe the contemporary world. In particular, it does not describe the globalised world in which the majority of people are highly urbanised and live in an environment very different from the primitive societies described by Vico. As a result, it is doubtful whether the argument that human institutions are based on the three principles which he derives from his description of primitive society can be sustained. Secondly, because the nexus between faith and reason has been broken as a result of the enlightenment project which sought to install reason as the final arbiter of truth. This has meant that an explanation for the nature of the world and of human institutions has been sought without reference to God or to a belief in the immortality of the soul. More recently, the idea of marriage as a cornerstone of human society, solemn matrimony in Vico's words, has also been seriously undermined. The postmodern turn of the late twentieth century in reaction to the enlightenment project, has gone further by seeking to overthrow even the primacy of reason and of the idea of objective truth. Once these are gone, there does not seem to be any way in which particular conceptions of human institutions can be justified.

The vacuum created by this has, arguably, allowed the primacy of the economic sphere to overwhelm and corrupt our conception of truth and to measure everything that human beings understand about the world and themselves in economic terms alone. ${ }^{5}$ The kind of world Vico describes is very different to the one inhabited by human beings today, but this does not mean that human desires and aspirations are so very different. Human beings are no less concerned with certainty and security in their lives and so with what it is to lead a good and fulfilled life. In Vico's world, though he is describing what he calls humanistic education, it is centred on the importance of wisdom as the aim of education, and this is closely linked to the idea that in 
knowing ourselves, we learn that we are created by God and meant for Him and hence, the wisdom we seek is found in God. Education, as described by Vico, promises the certainty and direction that is missing in conceptions of education which are not oriented to a quest for wisdom. Despite the differences between Vico's world and that of the twenty-first century, the need for wisdom does not change and even if we hold a bleak Hobbesian perspective on the world, a salient feature of human nature remains the need for human beings to live together in order to have a better chance of survival in a largely hostile and dangerous world, one beset by fears about climate change, ageing populations (in the Western world) and global financial crises. The need for the ability to make prudent and wise decisions not just in the public sphere but in the private sphere is more urgent than ever.

Vico writes that the first fathers of the pagan nations possessed all four of the classical virtues: justice, prudence, temperance and fortitude and from these, and the way in which the ancients applied these virtues, new principles of moral philosophy can be derived. These in their turn enable us to determine principles for the education of children. Vico says that all the studies of children should strive to form them in familial piety and to confirm them in religion and that until they are able to comprehend the state, revere and fear their fathers. As they mature, he says, they will be able to observe the religion of their fathers and to defend the state which preserves their families. Vico says families are founded on religion and commonwealths subsequently created through laws. (Vico, 1999: 10) What is important here is to recognise that though Vico sees education as largely concerned with moral education, the rationale for it is religiously based. Later, Vico says that if philosophy is to benefit humankind, it must raise and support us as frail and fallen beings, rather than strip us of our nature or abandon us in our corruption. He rejects the Stoics and the Epicureans, the former because they tell us to mortify our senses and the latter because they make the senses the determinants of how to act. He says this leads him to support the Platonists who affirm that there is divine providence, that human emotions should be moderated to become human virtues and that human souls are immortal. He sees these three ideas as the same as his three principles on which New Science is based. Vico sees philosophy as providing abstract knowledge of what is true through reasoning, philology, which he defines as history, grammar, literature, humanities in general, arguably, have contributed to our awareness of people's languages and deeds, including their domestic customs and laws, and their foreign wars, peaces, pacts, travels, and trade. (Vico, 1993:77-79)

Having noted that the distinguishing characteristic of human beings is their social nature, for Vico it follows that for him human fulfilment is seen in terms of its contribution to the good of the whole community. If someone wishes to gain the greatest benefit from studying the liberal arts then he or she should do so for the sake of the common good. There are good reasons, he says, for serving the common good, namely the good things that the State has provided - ability to learn, increasing profits, just laws, peace, as well as the wealth for parents to provide education for their children. (Vico, 1993: 96-97) He notes that in Roman times the most noble citizens of Rome believed that the practical wisdom that they had acquired in the service of the state should be rendered promptly and clearly for the good of its citizens. (Vico, 1993: 98-99) He argues against the distinction that is made between what is "useful" and what is "honourable", saying that those material things which are recognised as useful, such as money, goods and real estate are only so if they contribute to the greater good. The more honourable the goal, the greater the good and that if any person wishes to be of greatest service to the greatest number, then he or she should acquire as much learning as he or she is capable of. (Vico, 1993: 99-101) Vico chastises parents who reject liberal studies because they are not likely to lead to any material gain. He argues that those who want to succeed in public life need to have studied the humanities - theology, jurisprudence, medicine, the study of languages, of history, and of eloquence. He says that it is the studies which bear no immediate rewards which ought to be studied. In time, such studies will be able to bear fruit, he suggests, and he exhorts students to direct their studies to the common good and to avoid greediness. (Vico, 1993: 104-105) This is in considerable contrast to the economic rationalist, neo-liberal conception of modern education.

An outline of the importance of an orientation to the common good and to wisdom is continued in Vico's sixth oration. Here the theological themes of education are apparent through his discussion of the 
corruptibility of human nature due to our fallenness, which is revealed in the inadequacy of language, the opinions of the mind and the passions of the soul. Fortunately, there is a remedy to this proposed and this also has three parts, namely, eloquence, knowledge and virtue. All wisdom, he says, is contained in these three things to speak with dignity, to know with certainty and to act rightly. (Vico, 1993: 127-129) The tasks of wisdom are recognised as social and communal, and wise persons are enjoined to tame the impetuousness of fools, to prudently lead them out of error and to foster their good will through their virtue. All studies are to be directed to the improvement of character, the gaining of truth and virtue, to speak well in order that the common good is served. It is in assiduously applying ourselves to these tasks that wisdom, which is both the knowledge of divine things and prudent judgement about human things, is attained. (Vico, 1993: 132)

Vico's outline of the content of the education which is to form the basis of instruction is classical and drawn from a variety of Roman sources such as Cicero, Livy, Plutarch and Horace, as well as Plato. He mentions the importance of learning language, especially grammar, geometry and mathematics, physics, which includes knowledge of anatomy and medicine, metaphysics, moral theology and jurisprudence. Eloquence is emphasised because we ought to discourse in truth and use speech that is both appealing and logical. Languages, Latin and Greek, should be taught in childhood and mathematics in adolescence, since by learning to use reason, less reliance is placed on an emotional response. Finally, once the habit of reason is established, pupils ascend to the contemplation of incorporeal realities and finally to know God. The path to true wisdom, however, requires pure intentions, that is, human beings need to undertake their quest for wisdom with true motives, namely, its attainment for its own sake and not for selfish motives. That is, the quest for truth undertaken purely will mean that human beings will always be oriented to the attainment of what is good and, being in the habit of seeking the truth, will be unconcerned with self aggrandisement. Always choosing the good and cultivating within themselves the virtues, human beings can reach God and in doing so, will be able to exercise prudence in human affairs, firstly in their relations with one another and secondly in the exercise of their duties as citizens. In all of these studies, concludes Vico, through gaining wisdom, human beings put themselves in the service of the common good. (Vico, 1993: 133-139)

Although Vico does make suggestions about the content and sequence of education, he argues that what is taught has to follow a developmental path. Otherwise, he advises, nothing will be learned or what is learned will be jumbled and incoherent. What is most noticeable in this account of education is the rejection of the idea that the purpose of education is first and foremost vocational training designed to enable students to obtain good, well-paying jobs. Education is for the good of society, but this is not in the sense of providing either the State or employers with adequately trained individuals. It is in the sense that wise persons not only have mastery of themselves, but also have the practical wisdom to be able to contribute, through wise advice and decisions, to the common good. Though the importance of vocational training and the gaining of skills is undeniable, it is not the main purpose of education. The idea that the aim of education is wisdom, and hence, the attainment of God, is also central to Bonaventure's conception of education.

Bonaventure and Wisdom as the aim of education

In The Reduction of the Arts to Theology (De Reductione Artium Ad Theologiam) ${ }^{6}$, a very densely written treatise, Bonaventure distinguishes different kinds of understanding: (i) that kind pertaining to the mechanical arts or practical arts -such as lanificium (woolworking, ie weaving), armatura (equipment (armor) making ), agricultura (agriculture), venatio (hunting), navigatio (travel/ navigation), medicina (medicine) and theatrica ( drama or theatre); (ii) that kind of understanding that is the light of sensitive awareness (knowing) and is what is known through the five senses; (iii) understanding that is rational or philosophical understanding (lumen cognitionis philosophicae) and that has three parts, the first dealing with the truth of speech, the second with natural things (science) and the third with morality and (iv) the kind of understanding that is that of the truth of salvation and is the light of sacred Scripture. It is the light of understanding obtained from this final kind of understanding that is the highest. $^{7}$

Apart from this superior light, the three other kinds of understanding are also called lights by Bonaventure. The first he calls the exterior light (lumen exterius) and is associated with the mechanical or technical arts we have already mentioned, six of these supply the needs of the body, the seventh, supplying 
enjoyment. The second, the inferior light (lumen inferius), is the light associated with the five senses, and the third, is the interior light (lumen interius), and is the light of philosophical knowledge (lumen cognitionis philisophicae) and which has three divisions, rational, natural and moral. The light of natural philosophy concerns the truth of things, and enlightens the mind to discern the causes of being. It divides further into metaphysics, physics, and mathematics. Bonaventure's four lights resemble Augustine's method of the ascent to God, which he outlines in his Confessions. (Augustine, 1961: 211-232) Moreover, the four lights are ultimately unified into one light and this four-fold light is the illumination of all human knowledge. It is notable that here the lesser lights are still, nevertheless, lights which help to illuminate our understanding and because they are together united in one, cannot be dismissed as unimportant. They are an integral part of human life and so will play their part in the ascent to the Truth, which is the ultimate goal of all human beings. ${ }^{8}$

The first light is associated with the well being of the human body, its clothing, its feeding, protecting, healing and sheltering. These are practical requirements for the maintenance of human life, without which nothing else would be possible at all. The theatrical arts include not only drama, theatre itself, but also all kinds of other games and activities designed to divert human beings from their sorrows and cares and to provide entertainment. The second light involves the operation of the five senses which provide us with sensory perceptions that enable us to apprehend the natural world. Sensory perception, as Bonaventure says in the Itinerarium Mentis in Deum, is the first step in our movement towards God. (Bonaventure, 1956, Chapter 1, \#6)

Bonaventure presents a threefold division of philosophy into rational, natural and moral. He places metaphysics in natural philosophy, making it the highest of human sciences because it is concerned with the nature of things as beings, that is, how they exist and how they are caused. Bonaventure does not make it a science of God, however, because this would make metaphysics an autonomous rational theology. To do this would lead to a rationalism, according to Bonaventure, in which all knowledge depends on reason, including knowledge of the divine. (Cullen, 2006: 31) The problem with metaphysics is its tendency to take over - an autonomous metaphysics tends to render supernatural theology one of three things: (i) an addendum; (ii) a mythic and popular presentation of philosophy (Averroes); or (iii) an impossibility (Hegel). In (ii) and (iii) metaphysics is not only independent, it is the sole, authentic science of God. Bonaventure says that this makes philosophy a closed system and not open to a higher science. Theology has to be queen of sciences. Philosophy is the handmaiden. Philosophy is the organising discipline that serves as the link between the lower sciences and the higher science of theology. Philosophy discloses what Bonaventure would call the "Metaphysical Centre”, Christ the Divine Word and all knowledge reduces to this. (Cullen, 2006: 32)

Bonaventure proclaims the importance of philosophy, the third light, but makes it subordinate to theology, because he agrees with Augustine that the reality of God cannot be discovered in any of the senses, nor in the mind. God is in some mysterious way, present in and to him. Augustine reflects that he cannot find God in the images of material things, nor in his memory, nor his emotions. Augustine says that because God is Truth, He is found everywhere that human beings seek counsel. That is, everywhere that human beings strive to discover the truth. He notes, however, that not everyone will realise this. God is therefore beyond the reach of our reasoning, but is nevertheless mysteriously at hand. (Augustine, 1961: 230-231) The De Reductione can be seen as a reassertion of the Augustinian view of Christian paideia. It offers a comprehensive and synthetic view of education in which all human knowledge and art is grounded in the exemplar ideas of the Word of God and can be thought of as a medieval renewal of Augustine's account of the purposes of education found in De Doctrina Christiana. (Cullen, 2006: 89) Philosophy is the height of natural wisdom and is the culmination of the liberal arts. Philosophy, however, needs to be centred on God, and it is this distinctive orientation which motivates both the Augustinian and Bonaventurian quest for knowledge and which grounds Bonaventure's (and Augustine's) understanding of the purpose of education.

In Bonaventure's other great classic, The Mind's Journey into God [Itinerarium Mentis ad Deum], a work which complements the De Reductione, there is a great emphasis placed on the ability of human beings to acquire knowledge through direct observation. (Bonaventure, 1956, hereinafter Itinerarium) Although 
Bonaventure does not reject the role of rationality and of reason, he holds that it is through our observation and experience of the world that we learn. For example, we know that sugar is sweet because we have tasted it, not because we have produced a rational argument that it is sweet. Bonaventure does not hold a theory of direct perception, however, because he allows that judgement is involved in making sense of the perceptions that are received by the mind. (Gilson, 1938: 355) Body and soul are more tightly united than Aquinas and Aristotle allow and so observation is crucial because it is on what our powers of rational thought, of judgment, operate in order for us to have knowledge of the world. Thus, though the Creator's light illuminates everything, and we have only to open our awareness to be aware of the traces of Himself that the Creator leaves in the world, there is an ascent we have to make through the levels of thought in order to reach our final goal which is the contemplation of Wisdom itself, which is God.

What is illustrative of the steps which lead to the ascent to God is the distinction between what is inner and what is outer to us. By this Bonaventure means we begin from what the senses present to us from the outer world, which then leads us to reflection, using the powers of thought, and so is a process that takes place in our inward selves and this in turn stimulates the contemplation that leads upwards to God. Human beings use the powers of the senses, of imagination, reason, intellect, intelligence and the illumination of conscience to reach their final destination, which is God. This is, of course, no easy task, and requires our full attention and perseverance. Bonaventure says that a key element is our orientation to the goal of attaining wisdom and this is helped by prayer and meditation. (Itinerarium, Chapter 1, \#8) Bonaventure does not, however, dwell excessively on abstract thought and rationality, instead emphasises the role of our senses in concert with our rational capacities to observe and marvel at the beauty and complexity of the world. The world is indeed a marvellous place, and it is through paying attention to it that we are able to detect the traces of God within it. (Itinerarium, Chapter 2) By reflecting on our own rich inner world, such as our ability to reason, as well as the intellectual power that we possess to understand the meaning of words and to draw inferences, we come to a realisation that we can only do so by having an apprehension of the infinite and the perfect, and this, in its turn, leads us to conclude there is an Ipsum Esse, Being Itself. The final step in the journey, the full contemplation of God, is beyond our own powers to achieve, but requires God's helping hand, and this leads us into theology. (Itinerarium, Chapter 4)

Bonaventure's account of the ascent of human beings to God provides a very cogent and powerful picture of the aim of human existence and if we consider the implications for education, it is quite evident that the learning which enables us to acquire skills and the knowledge to engage in a particular vocation is not enough. It is only the initial step in the educative process, and while it is important, our eyes should always be fixed on the final step, which is contemplation of the Divine and our final transportation into God. No one, however, is able to understand this final mystical union, except the one who receives it, and he or she who received it will not unless he or she desires it and he or she will not desire it unless the fire of the Holy Spirit, sent by Christ, inflames his or her very marrow. ${ }^{9}$

While is it is very obvious that Bonaventure's view of the purpose of human life is theological and it might well be objected that it is a highly religious and pious account of the nature of wisdom, which it undeniably is, nevertheless, it re-orients us to a different way of looking at the purposes of education. It is, by any measure, a lifelong process requiring great discipline, dedication and attentiveness to the task of acquiring wisdom, rather than being content to collect a miscellaneous set of skills. Education is not simply a matter of acquiring more, it is also a matter of gaining more sophisticated understanding of what one has learnt. All our human faculties are involved in this process. We learn not just with our senses, but our minds, our intellect and intelligence. This hierarchy of increasing sophisticated understanding is what higher education aims at through its hierarchy of higher degrees. Though this does take us some distance towards the goal of attaining wisdom, it will only do so if the learner gives her or his complete attention to the truth and to the good. Bonaventure's quest for wisdom move us well beyond formal educative processes, but since there is an essential unity between the steps to wisdom, the final steps cannot be undertaken without the former. 
Bonaventure's conception of the world is typically Franciscan, since he sees the good of God in everything, beginning from the most rudimentary observation to the most complex theory. Bonaventure warns against intellectual arrogance, saying: "reading without repentance, knowledge without devotion, research without the impulse of wonder, prudence without the ability to surrender to joy, action divorced from religion, learning sundered from love, intelligence without humility, study unsustained by divine grace, thought without the wisdom inspired by God.” (Itinerarium, Prologue, \#4) Bonaventure assumes from the outset the existence of God, which is confirmed in his mind by wonder of creation around him. Of course, if one does not begin from a position of belief in God, then it is difficult how can come have awareness of God's presence, immanent in creation. Though this is an overtly religious position, a passion for truth leads us in the same direction. The scientist cannot begin to make any observations unless she firmly believes that what she is doing will to lead to the truth, that the selected methods will result in something that we can have confidence in accepting as being true. Moreover, there also has to be confidence that if we were to encounter the truth about something that we would be able to recognise it as the truth. Bonaventure's views in relation to becoming aware of the existence of God is no different - if we are sensitive to what the world around us reveals, then we will be able to see that God exists. The beginning of all Wisdom, however, lies in God.

\section{Conclusion}

While it is true that the three protagonists discussed could be said to have an overtly religious understanding of education, this does not detract from the central point that has been argued. These older conceptions of the aim of education as the acquisition of wisdom call us to rethink the emphasis on short term, measureable outcomes as the aim of education in current, economic rationalist conceptions. It points also to the shortsightedness of regarding education as having only instrumental value for the learner and as a commodity to be sold by the educator. Similarly, education cannot be regarded as a tool of governments or big business. There is in all three thinkers the somewhat radical thought that human beings as individuals are called to be answerable to a higher authority than government, big business or the community to which they belong. They are called to serve the truth and the good, and to recognise that there is ultimately mystery which human thought cannot penetrate. The radical view proposed here has practical consequences, as the call to "know oneself" is a call to be true to oneself and this has a moral imperative, since it is simultaneously a call to be true in our relationships with others, those closest to us, and those more broadly.

There is no doubt that if wisdom as the aim of education is taken seriously, that education takes on a very moral hue, and, if we take Whitehead, Vico and Bonaventure seriously, a religious hue as well. Moreover, in the latter case, it begins to take a very particular understanding of the nature of moral value and of the formation of human beings in good moral habits. This, however, should not be regarded as restrictive of human freedom, but rather the opposite, since it is evident that in order to gain wisdom we have to be prepared to discipline ourselves and this is a choice we must consciously make. It is evident that if we take seriously the proposition that the aim of education is the acquisition of wisdom, that it is not measureable because it requires insight, creativity and an ability to assess a situation and make the right judgement. No one can be called wise who makes wrong decisions or is unable to see clearly how different aspects of a situation come together. A wise person sees the interconnectedness of things, and is able to penetrate more deeply into reality and so see more clearly. This is not measureable because wisdom is most needed in novel situations and often in crises. Every nation, for example, wants wise leaders. This cannot be measured beforehand. There is a process of preparation, as we have outlined, but there is no guarantee that there will be a measureable outcome at the end of a period of study. As already indicated, it is a lifelong quest.

\section{Notes}

\footnotetext{
${ }^{1}$ Whitehead emphasises the importance of being able to utilise what has been learned, rather than learning more and more by saying : "It should be the chief aim of a university professor to exhibit himself in his own true character - that is, as an ignorant man, thinking, actively utilising his small share of knowledge. In a sense, he adds, knowledge shrinks as wisdom grows, for details are swallowed up in principles. The details of knowledge which are important, he
} 
says, will be picked up ad hoc in each avocation of life, but the habit of the active utilisation of well-understood principles is the final possession of wisdom." (1962: 58)

${ }^{2}$ Of course it may be argued that the Judaeo-Christian God is ineffable. What is meant here is that in Vico God plays a much clearer and obvious role than in Whitehead's account where God is altogether more mysterious and it is not clear that God is a personal God in the way in which the Judaeo-Christian God is.

${ }^{3}$ Plato (2008) Alcibiades I, tr. Benjamin Jowett, produced by S. Asscher, Project Gutenberg ebook, at URL http://www.gutenberg.org/files/1676/1676.txt Accessed: 16/8/2010. See also Plato (1952) The Dialogues of Plato, tr. Benjamin Jowett, Chicago: University of Chicago Press, Philebus 48c; and Charmides 164e-165a; it might also be linked to paiedea as suggested by Heidegger in his account of the cave in the Republic.

${ }^{4}$ Vico comes to these three principles through an historical account in which human beings firstly scattered throughout the world, living as brutes, but gradually coming together to live with a particular woman and have particular children, and taking shelter in certain places. Burial rites led to the establishment of clans and tribes, who were descendants of the buried dead. We shall not discuss Vico's three principles here in any detail save to note that what Vico provides is a naturalistic account of the origins of human institutions.

${ }^{5}$ Walzer introduces us to the spheres of justice and that argues that each sphere has its own criteria for what counts as justice. For example, the criteria of what counts as equality in education will depend on the sphere of education, that is, decided on educational criteria, while in the sphere of medicine this will depend on medical kinds of criteria. This has been corrupted by the intrusion of the economic sphere. That is, instead of measuring educational outcomes in terms of educational criteria, they are measured in economic terms. See Walzer, M. (1983).

${ }^{6}$ Hereinafter, De Reductione

${ }^{7}$ Bonaventure says, "Quartum autem lumen, quod illuminat ad veritatem salutarem, est lumen sacrae Scripturae, quod ideo dicitur superius, quia ad superiora ducit manifestando quae sunt supra rationem, et etiam, quia non per inventionem, sed per inspirationem a Patre luminum descendit." ["Now the fourth light, which illuminates for the purposes of a saving truth, is the light of sacred Scripture, which therefore is called superior, because it leads to what is revealed to be above reason, and actually to what is not through invention, but through inspiration by the light which descends from the Father.] (Author's translation) De Reductione, para. 5

${ }^{8}$ We have not tried to argue for this position. Many would object that the aim of their lives is much more modest: they simply want to be happy in this life, surrounded by their family and friends, and with sufficient material comfort, health and security. This is not denied, what is being argued here is that there is something more beyond this that human beings can aspire to and this is variously called Wisdom, Truth and God. Both Aristotle and Aquinas acknowledge that there is an imperfect kind of happiness which is the end of human life, but that there is also a happiness which reaches beyond this world. For a brief account of this, see Drum, P. (2010).

${ }^{9}$ Bonaventure says, "Hoc autem est mysticum et secretissimum, quod nemo novit, nisi qui accipit [Apoc., 2:17] nec accipit nisi qui desiderat, nec desiderat nisi quem ignis Spiritus sancti medullitus inflammat, quem Christus misit in terram." ["This, however, is mystical and most secret, which no one knows, except who accepts it and no one can accept it except who desires it and no one desires it except one who the fire of the Holy Spirit, who Christ sent upon earth, inflames to his marrow.”] Itinerarium, Chapter 7, \#4.

\section{References}

Augustine (1961) Confessions, tr. and intro. R.S. Pine-Coffin, Harmondsworth: Penguin

Bonaventure (1996) On the Reduction of the Arts to Theology (De Reductione Artium Ad Theologiam) tr. Z. Hayes OFM, Vol. 1 of Works of St. Bonaventure, ed. F. Edward Coughlin OFM, St. Bonaventure, New York: The Franciscan Institute

Bonaventure (1956) Itinerarium Mentis ad Deum, tr. Philotheus Boehner, OFM, Vol. 2. Of Works of Saint Bonaventure, ed. Philotheus Boehner and Sr. M. Frances Laughlin, SMIC, St. Bonaventure, New York: The Fransciscan Institute

Bouthillier, F. and Shearer, K. (2002). Understanding knowledge management and information management: the need for an empirical perspective, Information Research, 8(1), paper no. 141 At URL http://InformationR.net/ir/81/paper141.html Accessed: 11/8/2010.

Cullen, C.M. (2006) Bonaventure, Oxford: Oxford University Press

Drum, P. (2010) Aristotle and Aquinas on Human Fulfilment in God, Ethics Education, 16, 1, 40-43

Gallagher, M. (2000) The Emergence of Entrepreneurial Public Universities in Australia, paper presented at the IMHE General Conference of the OECD, Paris 2000, Canberra: Commonwealth of Australia, Department of Education, Training and Youth Affairs

Gilson, E. (1938) The Philosophy of St. Bonaventure, London: Sheed and Ward

Harvey, Sharon (2003) For knowledge society read knowledge economy? One future for tertiary education in New Zealand, HERDSA, Learning for an Unknown Future: HERDSA Conference Proceedings 2003, CD ROM, Christchurch: HERDSA, July 6-9, 2003

Liu, A. (2004) The Laws of Cool: Knowledge, Work and the Culture of Information, Chicago: University of Chicago Press

Lyotard, J-F. (1984), The Postmodern Condition: A Report on Knowledge, tr. Geoff Bennington and Brian Massumi, Forward by Frederic Jameson, Manchester: Manchester University Press 
Plato (2008) Alcibiades I, tr. Benjamin Jowett, produced by S. Asscher, Project Gutenberg ebook, at URL http://www.gutenberg.org/files/1676/1676.txt Accessed: 16/8/2010.

Plato (1952) The Dialogues of Plato, tr. Benjamin Jowett, Chicago: University of Chicago Press

Sawyer, K.R., Johnson, J. and Holub, M. (2009) Decline in Academe, International Journal of Academic Integrity, 5: 2, $10-28$

Scaratino, A. (2010) Information without Truth, Metaphilosophy, 41, 3, 313-330

Strech, D. (2010) How Factual Do We Want the Facts? Criteria for a Critical Appraisal of Empirical Research for Use in Ethics, Journal of Medical Ethics, 36, 4, 222-225

Thomson, I. (2001) "Heidegger on Ontological Education, or: How We Become What We Are”, Inquiry, 44, 243-268

Vico, Giambattista (1993) On Humanistic Education (Six Inaugural Orations 1699-1707), Tr. Pinton, G.A. and Shippe, A.W., Intro. Verene, D.P. Ithaca and London: Cornell University Press

Vico, Giambattista (1999) New Science, tr. Marsh, D. and intro. Grafton, A., Harmondsworth: Penguin

Walzer, M. (1983) Spheres of Justice: A Defense of Pluralism and Equality, New York: Basic Books

Whitehead, A.N. (1962) The Aims of Education and Other Essays, London: Ernest Benn Ltd 